\section{Past, Present, and Future of Jujubes-Chinese Dates in the United States}

\author{
Shengrui Yao' \\ Department of Plant and Environmental Sciences, Sustainable Agriculture \\ Science Center at Alcalde, New Mexico State University, 371 County Road \\ 40, Alcalde, NM 87511
}

Additional index words. Ziziphus jujuba, cultivar, biology, flowering, pests and diseases, nutrition, propagation, fruit use, processing

\begin{abstract}
This article summarizes jujube importation and culture history and current jujube cultivars in the United States. Described within are jujube taxonomy, biology, adaptation, fruit nutrition, pests and diseases, propagation, and research conducted in the United States. It also discusses the current issues with jujubes in the United States and possible solutions to them. Jujube adapted and grew well in the southern and southwestern United States, and it could become a valuable industry in the United States within 15 to 20 years.
\end{abstract}

Jujube (Ziziphus jujuba Mill), also called chinese date, red date, or tsao (zao), is native to China (Liu, 2006; Qu, 1963). It originated in the middle and lower reaches of the Yellow River and has been cultivated in China for more than 4000 years (Guo and Shan, 2010; Liu, 2006). Botanically, it is derived from its wild relative sour jujube or wild jujube $(Z$. spinosa $\mathrm{Hu}$ ). In ancient times, people selected and cultivated sour jujubes with big fruit and good flavor, and it gradually became the cultivated modern jujube species $(Z$. jujuba). There are still semicultivated sour jujubes like 'Tiger Eye', big round, sour jujube, and Yanjishan big sour jujube, which are popular in Beijing and Shandong Province, China, respectively (Guo and Shan, 2010).

Jujube was first dispersed within China from its original center and then to countries bordering China. It was through the famous "Silk Road" that jujubes were introduced to Europe at the beginning of the Christian era (Liu, 2006; Lyrene, 1979). It is widely distributed in Persia, Armenia, Syria, Spain, and France (Locke, 1948; Lyrene, 1979). Most early jujube imported to Europe were seedlings (Locke, 1955; Lyrene, 1979)

Received for publication 1 Mar. 2013. Accepted for publication 2 Apr. 2013.

This paper is partially supported by the USDA Specialty Crop Block Grant through the New Mexico Department of Agriculture. This is also a contribution of the New Mexico Agricultural Experiment Station, New Mexico State University, Las Cruces, NM.

I thank Steve Guldan, Richard Heerema, and Geno Picchioni from New Mexico State University for their critical review of the manuscript. I also thank Martha Davis from Los Alamos, NM, and Roger Meyer from Fountain Valley, CA, for their comments and suggestions.

${ }^{1}$ To whom reprint requests should be addressed; e-mailyaos@nmsu.edu. and were used as a table dessert or winter sweetmeat.

Liu (2006) reviewed the jujube basics and research in China and worldwide. Lyrene (1979) briefly summarized the jujube tree situation in the United States. This review focuses on the cultivar history, biology, adaptation, and production challenges in the United States and makes a comparison with the jujube situation in China whenever necessary.

\section{Jujube History in the United States}

Robert Chisholm first brought jujube seedlings to the United States and planted them in Beaufort, NC, in 1837 (Rehder and Rixford, 1929). In 1876, G.P. Rixford brought jujubes from southern France to California's Sonoma Valley and neighboring states (Rehder and Rixford, 1929). By 1901, jujube had escaped from cultivation and naturalized along the Gulf Coast from Alabama to Louisiana (Bonner and Rudolf, 1974; Lyrene, 1979). All of those early imports were seedling plants from Europe, not vegetatively propagated cultivars. It was not until 1908 that USDA agricultural explorer Frank $\mathrm{N}$. Meyer introduced the first group of commercial jujube cultivars directly from China (Meyer, 1911). Meyer mentioned that one of the most promising tree crops of China was the chinese jujube, and he predicted jujube would be of great value in the semiarid south and southwest United States (Meyer, 1916). Jujube was one of two plants sculpted on the Frank N. Meyer Memorial Medal from the American Genetic Association in recognition of his contribution to plant germplasm collection and use (Fairchild, 1920).

\section{Jujube Cultivars in the United States}

The jujube cultivars in the United States now include several groups: Frank Meyer's direct imports from China, U.S. cultivars from the USDA Chico jujube program, selections from across the United States, and recent imports from China or other jujubegrowing countries (Table 1). Those in Table 1 were listed as cultivars, but only a few of them were formally named, released, and went through cultivar trials.

Cultivars imported through Frank Meyer and the remaining cultivars currently in the United States. Frank N. Meyer reportedly made four trips to China (1905-08, 1909-11, 1912-15, and 1916-18) (Plantexplorers.com, 2012). Locke (1948) mentioned that 83 of 2500 of Meyer's PIs to the United States were jujubes. The author went through all the 1905-18 PI records (online now) and found that 67 jujube accessions were directly imported by Meyer from China (Table 2) (Galloway, USDA, 1907, 1908, 1909a, 1909b, 1912; Taylor, USDA, 1916a, 1916b, 1917a, 1917b, 1917c, 1922a, 1922b). Besides Frank Meyer's collection, others also collected 20 jujube accessions from 1905 to 1918 with 14 from China, four from the United States, one from Paris, and one from Asia (Table 3) (Galloway, USDA, 1909c, 1910, 1911a, 1911b, 1911c, 1911d; Taylor, USDA, 1914a, 1914b, 1915, 1917a, 1917c, 1919). Later, those accessions were rarely mentioned in literatures.

Table 2 indicates that Meyer visited the five major jujube-producing provinces in China: Hebei (formerly Chihli), Shandong, Shanxi, Shaanxi, and Henan Provinces as well as the Beijing and Tianjin areas. Frank Meyer collected roots or budwood of an unknown big-fruited cultivar during his first trip in 1905 , which possibly did not survive because this was his first jujube import without any rootstock preparation, and the shipment itself may have been problematic. He sent back 12 batches of jujube seeds from jujube cultivars and sour jujube (Z. spinosa) from 1905 to 1907 . Some of those seeds were collected in Sept. 1907 from famous cultivars like 'Chin sze tsao' (Jinsi zao in Chinese), 'Yuen ling tsao' (Yuanling zao), and two rare flat cultivars like mini apples in Shandong Province. In Mar. 1908, Meyer collected budwood for the famous 'Lang' and 'Mu shing hong tsao' together with 'Hu ping tsao' (Huping zao) and 'Tsui ling tsao' (Cuiling zao) from Shanxi Province. The USDA Chico Station received them in 20 Apr. 1908, which opened a new era for jujubes in the United States with big-fruited cultivars.

Meyer collected the major cultivars in each region, like 'Chin sze tsao', 'Yuen ling tsao', 'Lang tsao', 'Hu ping tsao', and 'Ta tsao' (big-fruited tsao) and 'Hsiao tsao' (small-fruited tsao). However, 'Ta tsao' and 'Hsiao tsao' are different from region to region, which usually refer to the two local dominant cultivars, but they are different in size. He also collected some rare cultivars-a flat one resembling a mini apple, a seedless (pitless) one named 'Wu hu tsao' (Meyer, 1911), 'Yu tsao' (Ya zao, tooth-shaped), a contoured one with gnarled and zigzagged branches, 'So' (PI 37484), and another one with crooked and twisted branches called 
Table 1. Current jujube cultivars in the United States.

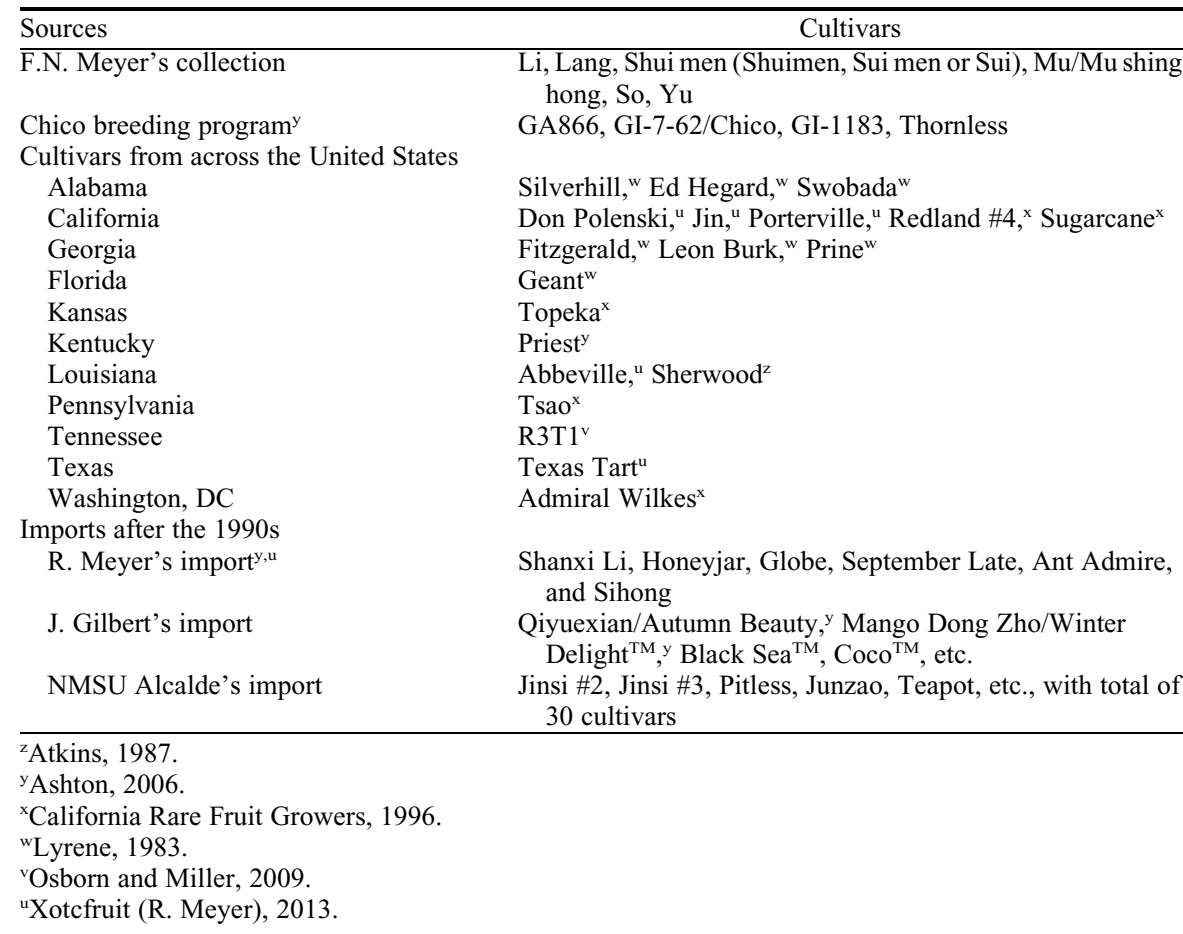

'Dragon' or 'Dragon's-claw' (Meyer, 1911). He also intentionally collected wild jujube seeds as rootstocks (Meyer, 1911) and seeds from trees with good fruit flavor for cultivar breeding purposes (Table 2). Meyer mentioned several times the hen egg-sized jujube fruit, and 'Li' was one of them. Of the 67 accessions imported, the very first one (PI 17752) was an unknown cultivar, 35 were vegetative parts from 34 cultivars (two ' $\mathrm{Wu}$ hu tsao' from different locations), one accession was a rooted plant from one of those 34 cultivars, and another one was a sample of dried fruit; the other 29 accessions were seeds from either $Z$. spinosa (three accessions) or $Z$. jujuba cultivars (26 accessions). All of Frank Meyer's introductions were first planted at the USDA Plant Introduction Station at Chico and were later distributed to other USDA stations, especially in Dalhart, Big Spring, and Lubbock, TX; Woodard and Lawton, OK; Garden City, KS; and Tucumcari, NM (Locke, 1948). In the mid-1930s, J.L. Collins of the Tennessee Valley Authority tested 40 cultivars near Norris, TN, and 'R3T1' (Row 3 , Tree 1) was a selection from that planting (Osborn and Miller, 2009).

In the 1920s, the USDA Chico Station recommended four cultivars - 'Mu shing hong' (PI 22684), 'Lang' (PI 22686), 'Shui men' (PI 38245), and 'Li' (PI 38249) (Thomas, 1927). 'Mu shing hong' was described as "one of the best varieties"; 'Lang' was "the best variety for general purposes"; 'Shui men' was "of average size and useful for many purposes"; and ' $\mathrm{Li}$ ' had "the largest fruit and is one of the best to eat fresh and ripened one to two weeks later." Coincidently, all four cultivars were originally imported from Shanxi Province. Locke (1948) mentioned three of the four cultivars without 'Mu shing hong'.
The observation and research work on jujubes at the USDA Chico Station continued

Now 'Li' and 'Lang' are the two most available cultivars in the United States. 'So', 'Yu', 'Mu' (Mu shing hong), and 'Shui men' of Frank Meyer's importation are also available in small quantities at Fountain Valley, $\mathrm{CA}$, a private collection of Roger Meyer (not directly related to Frank Meyer), who is a jujube enthusiast and vice-president of California Rare Fruit Growers [Xotcfruit (R. Meyer), 2013].

Cultivars from the USDA Chico breeding program. There were several cultivars bred at the USDA Chico Station by Dr. Ackerman and his colleagues, although most of them were not officially released.

'Chico', also called 'GI-7-62', bred at the USDA Chico Station, is a seedling of PI 37484 ('So') with round but flattened fruit. Paul H. Thomson, who is one of two founders of California Rare Fruit Growers, named it 'Chico' to remember the Chico Station in California (Thomson, 1971). 'GI-1183' is another cultivar from the USDA Chico Station bred by Ackerman from unknown sources (Ashton, 2006). 'GA866' is a cultivar bred and selected at the USDA Chico Station by Ackerman with unknown sources (Ashton, 2006; California Rare Fruit Growers, 1996). 'Thornless' is a cultivar bred/selected at the USDA Chico Station by Ackerman and Smith; the fruit shape is similar to 'Lang' and the source is unknown (Ashton, 2006).

Cultivar/selections from across the United States. The United States does not have large germplasm resources (gene pool) for cultivar selection like China does, but after more than 175 years of jujube cultivation in the United States, there are some jujube plants with great until the end of the 1950s (Ackerman, 1961). fruit quality scattered in people's backyards without names. Locke (1948) mentioned that the patent office distributed jujube seeds to interested people in 1854 . This is why there are many cultivars from different states named after people or towns, which are the result of long-term selections from seedlings or survivors of Frank Meyer's imports. Some of them could be the same cultivar but were found and renamed at other locations. Genetic analyses are needed to clarify their relationships. To date, there has not been much genetic or molecular work on jujubes for cultivar classification and grouping in the United States.

Some cultivars from this group are of sufficiently high quality to be officially named, but most of them lack regional tests. For example, 'Sherwood' (Atkins, 1987) was an excellent cultivar for California, Texas, and Louisiana, but it has poor fruit set and does not ripen before first frost in northern New Mexico. The author noticed several jujube trees 30 to 50 years old or older across New Mexico with good quality for both fresh eating and drying that would be worth further attention and testing.

Recent imports from China and other jujube-growing areas. In California, Roger Meyer imported several cultivars from China's Nanjing Botanical Garden in the 1990s [Xotcfruit (R. Meyer), 2013]. Jim Gilbert of One Green World Nursery in Oregon, introduced 'Autumn Beauty' and 'Winter Delight'TM from China (Ashton, 2006) and several cultivars from the Ukraine (personal communication) and the New Mexico State University Sustainable Agriculture Science Center at Alcalde, NM, directly imported over 30 cultivars from China in 2011. Cultivar evaluation trials are greatly needed across the United States to move jujube production forward. Growers need more cultivars for different purposes and to extend their harvest seasons.

The jujube cultivars in China have changed and increased rapidly after 1980 and especially since the 1990s. Researchers have done significant work on jujube germplasm collection and selections. An increasing number of new selections were named after 1990, but hybridization breeding is still problematic as a result of jujube's tiny flower and the multiple flowers in a florescence (Liu, 2006). There are over 800 jujube cultivars in China now (Guo and Shan, 2010). There are total of 60 to 70 "cultivars" in the United States, but only a few of them are commercially available. Hopefully, after several years of research and evaluation, we will be able to recommend 10 to 20 cultivars for different purposes to growers.

\section{Taxonomy and Biology}

Jujube belongs to the Rhamnaceae (Buckthorn) family. Its close relative is the sour jujube, from which cultivated jujubes were selected (Liu, 2006). Sour jujube grows in the wild in the mountainous areas of northern China. It is sometimes used as hedgerows, 


\begin{tabular}{|c|c|c|c|c|c|c|}
\hline PI no. & Colleting date & Plant part & Name & $\begin{array}{l}\text { Chinese } \\
\text { name }\end{array}$ & $\begin{array}{l}\text { Collecting } \\
\text { location }\end{array}$ & $\begin{array}{c}\text { Province/area } \\
\text { (now) }\end{array}$ \\
\hline 17752 & 20 Mar. 1905 & $\begin{array}{l}\text { Roots or bud sticks of a large- fruited } \\
\text { cultivar }\end{array}$ & $\mathrm{N} / \mathrm{A}$ & & Chang-li, Chihli & Hebei $^{z}$ \\
\hline 17892 & 20 Mar. 1905 & Seeds of sour jujube & Suan tsao & & & Hebei \\
\hline 18565 & 20 Mar. 1905 & Seeds & N/A & & Peking & Beijing \\
\hline 19394 & 5 Oct. 1905 & $\begin{array}{l}\text { Seeds from market of a large- fruited } \\
\text { cultivar }\end{array}$ & $\mathrm{N} / \mathrm{A}$ & & Peking & Beijing \\
\hline 19397 & 26 Oct. 1905 & Seeds & N/A & & Pee-san & Hebei (?) \\
\hline 20092 & 26 Sept. 1906 & Seeds of a large-fruited cultivar & $\mathrm{N} / \mathrm{A}$ & & Vladivostok, Siberia & Siberia \\
\hline 21618 & 30 Sept. 1907 & Seeds & Chin sze tsao & 金丝本 & Laoling, Shandung & Shandong \\
\hline 21619 & 7 Sept. 1907 & Seeds & Yuen ling tsao & 园铃查 & Shantung & Shandong \\
\hline 21993 & Aug.-Sept. 1907 & Seeds mixture from different locations & N/A & & Shantung & Shandong \\
\hline 21994 & 22 Aug. 1907 & Seeds & Twen ku lu tsao & 礅轱轳責 & Chingcliowfu, Shandung & Shandong \\
\hline 21995 & 19. Sept. 1907 & Sour jujube seeds & Suan tsao & 酸麥 & Boshan, Shantung & Shandong \\
\hline 21996 & 22 Sept. 1907 & Seeds & Tun ku yu tsao & & Chinanfu, Shantung & Shandong \\
\hline 22606 & 9 Dec. 1907 & Seeds & $\mathrm{N} / \mathrm{A}$ & & Jehol, Chihli & Hebei \\
\hline 22683 & 1 Mar. 1908 & Budwood & $\mathrm{Hu}$ ping tsao & 壶瓶東 & Tsintse, Shanxi & Shanxi \\
\hline 22684 & 10 Mar. 1908 & Budwood & Mu shing hong tsao & 木星红本 & Tsintse, Shanxi & Shanxi \\
\hline 22685 & 10 Mar. 1908 & Budwood & Tsui ling tsao & 脆铃菄 & Tsintse, Shanxi & Shanxi \\
\hline 22686 & 10 Mar. 1908 & Budwood & Lang tsao & 郎疋 & Tsintse, Shanxi & Shanxi \\
\hline 22914 & 1 Apr. 1908 & Budwood & Lung tsao tsao shu & 龙麥 & Tientsin, Chihli & Tianjin \\
\hline 30411 & 10 Nov. 1912 & Seeds & $\mathrm{N} / \mathrm{A}$ & & Chinese Turkestan & Xinjiang (?) \\
\hline 31737 & 4 May 1911 & Dried fruits, tree originally from Honan & $\mathrm{N} / \mathrm{A}$ & & Chugutchak, Mongolia & Mongolia \\
\hline 35253 & 30 Mar. 1913 & Cuttings & Wu hu tsao & 无核枓 & Laoling, Shantung & Shandong \\
\hline 35254 & 30 Mar. 1913 & Cuttings & Wu hu tsao & 无核本 & Laoling, Shantung & Shandong \\
\hline 35255 & 30 Mar. 1913 & Cuttings & Tze lin tsao & 大铃椟 & Laoling, Shantung & Shandong \\
\hline 35256 & 30 Mar. 1913 & Cuttings & Tang tsao & 糖查 & Laoling, Shantung & Shandong \\
\hline 35257 & 30 Mar. 1913 & Cuttings & Hsiao tsao & 小本 & Laoling, Shantung & Shandong \\
\hline 35260 & 30 Mar. 1913 & Rooted plants of 35253 & & & Laoling, Shantung & Shandong \\
\hline 35287 & 18 Mar. 1913 & Sour jujube seeds & Suan tsao & 酸臬 & Peking & Beijing \\
\hline 35601 & 1 Apr. 1913 & Seeds (scion is 35255 ) & & & Tsinan, Shantung & Shandong \\
\hline 35602 & 1 Apr. 1913 & Seeds & Pou hong ta tsao & 泡红大本 & Peking & Beijing \\
\hline 35603 & 1 Apr. 1913 & Seeds & Yuan ling tsao & 园铃疋 & Tsinan, Shantung & Shandong \\
\hline 35604 & 1 Apr. 1913 & Seeds & Ta hong tsao & 大红疋 & Tientsin & Tianjin \\
\hline 35605 & 1 Apr. 1913 & Seeds & Ta hsiao hong tsao & 大小红本 & Peking & Beijing \\
\hline 35606 & 1 Apr. 1913 & Seeds & Hsiao tsao & 小柬 & Tsinan, Shantung & Shandong \\
\hline 35607 & 1 Apr. 1913 & Seeds & Hsiao tsao & 小皮 & Tientsin & Tianjin \\
\hline 35608 & 1 Apr. 1913 & Seeds & Rho hsiao tsao & 肉小東 & Tientsin & Tianjin \\
\hline 35609 & 1 Apr. 1913 & Seeds & Pou hong hsiao tsao & 泡红小疋 & Peking & Beijing \\
\hline 36852 & 7 Nov. 1913 & Budwood & Ta tsao & 大東 & Peking & Beijing \\
\hline 36853 & 8 Nov. 1913 & Budwood & Hsiao tsao & 小柬 & Peking & Beijing \\
\hline 36854 & 9 Nov. 1913 & Budwood & Yu tsao & 牙臬 & Peking & Beijing \\
\hline 37475 & 23 Dec. 1913 & Budwood & Ta tsao & 大本 & Lingpao, Honan & Henan \\
\hline 37476 & 24 Dec. 1913 & Budwood & Ta kungTsao & 大红東 & Lingpao, Honan & Henan \\
\hline 37484 & 6 Jan. 1914 & Budwood & So Tsao & 酥菄? & Sianfu, Shensi & Shaanxi \\
\hline 37489 & 8 Jan. 1914 & Budwood & Lung chao tz'u shu & 龙爪刺树 & Sianfu, Shensi & Shaanxi \\
\hline 37659 & 4 Feb. 1914 & Budwood & Ma lieu tsao & 马连本 & Sianfu, Shensi & Shaanxi \\
\hline 37668 & 10 Feb. 1914 & Budwood & Ta tsao & 大東 & Shansi & Shanxi \\
\hline 38187 & 14 Mar. 1914 & Budwood & Ta tsao & 大查 & Kuyehsien, Shantung & Shandong \\
\hline 38243 & 14 Feb. 1914 & Budwood & Ta Yuan tsao & 大园本 & Paihsiangchen, Shanxi & Shanxi \\
\hline 38244 & 14 Feb. 1914 & Budwood & Tiao tsao & 条本 & Paihsiangchen, Shanxi & Shanxi \\
\hline 38245 & 14 Feb. 1914 & Budwood & Shui men tsao & 水门本 & Paihsiangchen, Shanxi & Shanxi \\
\hline 38246 & 14 Feb. 1914 & Budwood & Chi hsin tsao & 鸡心本 & Paihsiangchen, Shanxi & Shanxi \\
\hline 38247 & 14 Feb. 1914 & Budwood & Yuan ts'ui tsao & 园脆查 & Paihsiangchen, Shanxi & Shanxi \\
\hline 38249 & 14 Feb. 1914 & Budwood & Li tsao & 梨本 & Anyihsien, Shanxi & Shanxi \\
\hline 38250 & 14 Feb. 1914 & Budwood & P'o p'o tsao & 婆婆本 & Anyihsien, Shanxi & Shanxi \\
\hline 38251 & 14 Feb. 1914 & Budwood & Ken tsao & 硬菄 (?) & Anyihsien, Shanxi & Shanxi \\
\hline 38252 & 14 Feb. 1914 & Budwood & Kuai tsao & 弯本 & Anyihsien, Shanxi & Shanxi \\
\hline 38253 & 14 Feb. 1914 & Budwood, less twisted than 38252 & & & Anyihsien, Shanxi & Shanxi \\
\hline 38258 & 27 Feb. 1914 & Budwood & Hui tsao & 灰妻 & Wulipu, Honan & Henan \\
\hline 38260 & 27 Feb. 1914 & Budwood & Chui yueh ch'ing tsao & 九月青素 & Honan & Henan \\
\hline 38261 & 27 Feb. 1914 & Budwood & Ma ya t'ou tsao & 马牙头㫡 & Honan & Henan \\
\hline 38359 & 27 Feb. 1914 & Budwood & $\mathrm{Su}$ tsao & 酥菄 & Honan & Henan \\
\hline 39194 & 20 Jun 1914 & Seeds & Hsiang tsao & 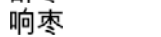 & Peking & Beijing \\
\hline 40506 & 20 Jan. 1915 & Budwood & Chin tsao or Fei tsao & 金本或肥東 & Pinchow, Shensi & Shaanxi \\
\hline 40877 & 20 Jan. 1915 & Seeds of 40506 & Chin tsao or Fei tsao & 金柬或肥查 & Pinchow, Shensi & Shaanxi \\
\hline 40878 & 31 Jan. 1915 & Seeds of 37476 & $\mathrm{~N} / \mathrm{A}$ & & Lingpao, Honan & Henan \\
\hline 40899 & 5 May 1915 & Seeds for rootstocks & $\mathrm{N} / \mathrm{A}$ & & Peking & Beijing \\
\hline 44203 & 16 Dec. 1916 & Seeds from big fruits for new selection & $\mathrm{N} / \mathrm{A}$ & & Peking & Beijing \\
\hline 44687 & 16 Dec. 1916 & Small fruits used for seeds as rootstocks & $\mathrm{N} / \mathrm{A}$ & & Peking & Beijing \\
\hline
\end{tabular}

${ }^{2}$ Chihli was the old name for Hebei Province, China.

$\mathrm{N} / \mathrm{A}=$ not available in the original reference. 
and local people also collect the fruits for its seeds, which is a traditional Chinese herb "suanzaoren," or use the fruits for soft drinks or further processing. It is also sold as snacks directly when freshly picked during harvest time in small quantities (Guo and Shan, 2010). The fruits of sour jujube are small and puffy without much flesh between the skin and the seed; however, it has higher vitamin $\mathrm{C}$ and titratable acid contents than jujube cultivars (Wang et al., 1956). Indian jujube, or ber, is also from the same genus (Ziziphus mauritiana) and is widely planted in India and nearby countries (Baloda et al., 2012). Jujubes are also known as chinese dates as a result of the similarity in appearance of dried jujube fruit and dried date (date palm, Phoenix dactylifera). Interestingly, the Chinese word for date palm ("zongzao") literally means palm jujube as a result of its similarity to jujube.

Jujube is a small tree of 20 to 30 feet depending on location with strong and hard wood. Its leaves are shiny, ovate or oval in shape, not branched, and alternate. Leaves are 2.5 to $5.5 \mathrm{~cm}$ long and 2 to $4 \mathrm{~cm}$ wide.

Buds and shoots. Jujube shoots are different from other fruit species. Vigorous new shoots of peach, apple, and grape can have branches in the same growing season, and the branches have similar structure to the primary shoot. Jujube has four types of shoots: primary (extension) shoot, secondary shoot (side branches), mother-bearing shoot (fruiting spur), and fruit-bearing shoot (branchlet) (Fig. 1). There are three kinds of jujube buds: main buds, secondary buds, and dormant buds (Liu, 2006; Yao, 2012a).

There are two buds, one main bud and one secondary bud, at each node of both the primary and secondary shoots and at the apex of the mother-bearing shoots. The terminal main bud of the primary shoot will keep growing each season to expand the tree canopy, and the lateral main buds (at the base of each secondary shoot) normally do not sprout and become dormant except with strong stimulation. The secondary buds on each node of the primary and secondary shoots are early-maturing buds, which produce secondary shoots or fruit-bearing shoots (Yao, 2012a).

The jujube primary shoot is always accompanied by secondary shoots (side branches), or the secondary shoots are part of the primary shoot and later diverge in function. The primary shoot elongates every year to expand the tree canopy. The secondary shoot acts as a base for the fruiting structure, does not extend in length, and withers back after 2 or 3 years. At each node of the secondary shoot is a motherbearing shoot (fruiting spur), which is a compact spur that grows $\approx 1 \mathrm{~mm}$ and produces two to five fruit-bearing shoots each year. The fruit-bearing shoot (branchlet) is thin, flexible, deciduous, and 10 to $20 \mathrm{~cm}$ long; it bears flowers and fruits at its axils. The primary shoot, secondary shoot, and branchlet are zigzagged and spiny (Yao, 2012a).
Flowers and fruit. Unlike apples or peaches, jujubes do not have big, showy flowers. Its flowers are fragrant, pale greenish yellow in color, and small with diameters ranging from 4 to $8 \mathrm{~mm}$ (Fig. 2). A jujube flower has five sepals, five petals, five anthers, and one ovary with two ovules (Yao, 2013). The five sepals are connected and sealed before anthesis. The anther and petal are isometric between sepals, and the petals are spoon- or cup-like and hold the anthers until pollen-dispensing. The nectary disk around the ovary is full of nectar during bloom and attracts insect visitors. Flower buds initiate as the branchlets grow. Flowers can appear singly or in a cluster at each leaf axil. Jujube's flower cluster (inflorescence) is a cyme (Fig. 2) with up to 13 flowers depending on the cultivar and its position on the branchlet. Jujube flower buds initiate, bloom, and develop to mature fruit within one growing season, which is unique and different from most tree fruit crops. Jujubes bloom for several weeks, making jujubes good nectar plants for the Asian honeybee (Apis cerena) in China. However, in the United States, the western honeybees (Apis mellifera) rarely visit the jujube flowers in New Mexico, and a jujube grower in California has made a similar observation (Roger Meyer, personal communication).

Jujube fruit is a drupe with one pit (stone) in the middle containing up to two seeds. Its fruit derives from its ovary and the nectary disk (Liu, 2006; Yao, 2013). Fruit size varies from thumb-sized to golfball-sized depending on the cultivar. The fruit shape can be round, oblong, oval, ovate, obovate, oblate, apple-like, or abnormally shaped (Liu, 2006) (Fig. 3). Jujubes are very precocious: they

Table 3. Jujube accessions collected from 1905-18 by others excluding Frank N. Meyer.

\begin{tabular}{lllll}
\hline PI no. & \multicolumn{1}{c}{ Location } & \multicolumn{1}{c}{ Presenter } & \multicolumn{1}{c}{ Cultivar } & Plant part \\
\hline 23455 & Beaufort, SC & F. Chisolm & N/A & Stock \\
24573 & Kutais Province, Transcaucasia & N.E. Hansen & N/A & Fruit \\
25777 & Paris, France & N/A & N/A & Stock \\
26109 & Hangchow, China & J.H. Judson & N/A & Plant \\
28764 & Las Cruces, NM & David Griffiths & N/A & Seeds \\
28926 & Shandong, China & T.J. League & Chang hung tsao & Cuttings \\
28927 & Shandong, China & T.J. League & Yuan ling tsao & Cuttings \\
29356 & Shandong, China & J.S. Whitewright & N/A & Roots \\
34054 & Tientsin, China & Yamei Kin & N/A & Seeds \\
34162 & Washington, DC & L. Reynolds & N/A & Plant \\
34874 & Peking, China & N.S. Hopkins & N/A & N/A \\
37069 & Tientsin, China & Yamei Kin & Ya hu tsao & Budwood \\
37070 & Tientsin, China & Yamei Kin & Kang tsao & Budwood \\
39477 & China & Paula Ritter & N/A & N/A \\
42046 & Shorter, AL & C.G. Howard & N/A & Cuttings \\
42305 & Damingfu, Chihli & J.G. Cole & Pu tao tsao & Cuttings \\
42306 & Damingfu, Chihli & J.G. Cole & Tan tsao & Cuttings \\
42307 & Damingfu, Chihli & J.G. Cole & Pu tao tsao & Cuttings \\
42308 & Damingfu, Chihli & J.G. Cole & Pu tao tsao & Cuttings \\
42309 & Damingfu, Chihli & J.G. Cole & Ma yu tsao & Cuttings \\
\hline
\end{tabular}

$\mathrm{N} / \mathrm{A}=$ not available in the original reference.

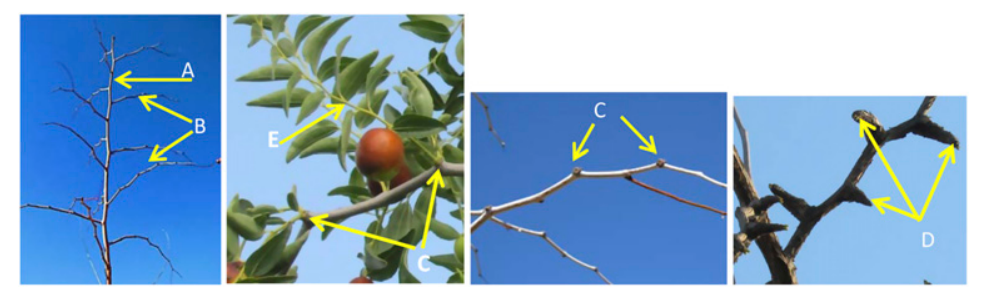

Fig. 1. Jujube shoot structures: (A) primary shoot, (B) secondary shoot, (C) mother-bearing shoot (young fruiting spur), (D) old fruiting spur, (E) fruit-bearing shoot (branchlet) (Adapted from Yao, 2012a).

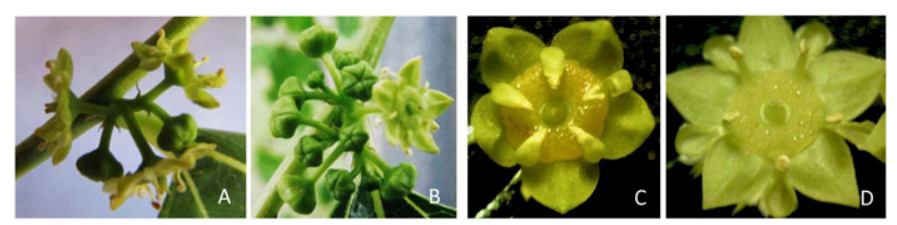

Fig. 2. Jujube flowers: (A) a simple cyme, (B) a large cyme, (C) a half-opened flower, (D) a fully opened flower (Adapted from Yao, 2012a). 
normally set some fruit the second year after planting and even sometimes set fruit during the year of planting or grafting.

Jujubes have morning blooming type and afternoon blooming type (Lyrene, 1983; Yao, 2012b). In China, a lot of dominant cultivars were self-fruiting, some cultivars performed better with cross-pollination, and a few of them were self-fruitless or self-sterile without pollen (Guo and Shan, 2010; Wang et al., 2006; Yan et al., 2010). However, crosspollination always increases fruit set and improves fruit size, quality, and seed development. Some home gardeners have pollination problems in the United States. Until a thoroughly jujube fruit pollination and fruit set study has been completed, it is recommended to plant two cultivars for crosspollination. There were a few reports about parthenocarpic cultivars, but more research is needed on this as a result of the tiny jujube flower and replication issues (Guo and Shan, 2010; Lyrene, 1983).

\section{Jujube's Adaptation and Culture}

Jujubes adapt well to a wide range of soil and weather conditions. They grow across China except in Heilongjiang and Jilin Provinces and the Tibet region. Jujubes grow from 0 to $2000 \mathrm{~m}$ elevation, between lat. $18^{\circ} 14^{\prime}$ to $45^{\circ}$ and long. $76^{\circ}$ to $124^{\circ}$, and in soil $\mathrm{pH} 5.5$ to 8.5 (Guo and Shan, 2010; Liu, 2006). In the United States, they grow from Pennsylvania, Washington, DC, North Carolina, South Carolina, to Florida, then from Florida, Georgia, Tennessee, Louisiana, Mississippi, Oklahoma, Texas, Kansas, New Mexico, Arizona, to California (Ashton, 2008; Brubaker, 1977; Locke, 1948; Lyrene and Crocker, 1994). Fairchild (1918) reported that jujubes could tolerate $48.9^{\circ} \mathrm{C}$ in the summer in northern California and withstood $-30{ }^{\circ} \mathrm{C}$ in the winter. Jujubes have been shown to grow and fruit well in the hot and arid southwestern United States (Locke, 1955; Meyer, 1911; Thomas, 1927; Yao, 2012a). In China, the story is similar: Hebei, Henan, Shandong, Shanxi, and Shaanxi are traditionally the five dominant jujube-producing provinces, but during the last 20 years, jujube plantings in the Xinjiang region, where the climate is hot and arid, have produced the best fruits in China with prices two to three times higher than others (Liu, 2008). Because jujubes like full sunshine and tolerate hot weather, the southwestern United States is an ideal location for jujubes where the arid climate also restricts many disease problems.

Numerous authors have mentioned the reliability of jujubes as a crop (Fairchild, 1918; Hager and Edward, 1989; Lanham, 1926; Locke, 1948; Lyrene, 1979; Meyer, 1916; Thomas, 1927; Yao, 2012a). With its late-season start-up, it avoids much of the late frost threat and, as a result, jujube trees rarely miss a crop. Jujube normally leafs out 4 to 6 weeks later than most temperate tree fruit crops and it blooms even later and continues blooming for 2 months or longer. Because it finishes flower bud initiation, blooming, fruit setting, and maturing within one growing season, it is not directly affected by the previous year's weather or pest problems that, for other fruit, may have a carryover effect on return bloom.

Jujubes are drought-tolerant (Hager and Edward, 1989). The tree can survive with an annual rainfall of only $200 \mathrm{~mm}$, but for better fruit set and fruit quality, more precipitation or supplemental irrigation is needed. In Tucumcari, NM, there are several untended jujube patches that were planted in the 1930s (Fig. 4). They spread by seeds or by root suckers on dryland sites without any irrigation or care and have survived for 80 years. The trees can survive extremely dry weather and will set fruit in wet years, which makes them good backyard or landscape trees.

\section{Nutrient Contents}

Jujubes have been used in China as fruit and a traditional Chinese herb for a long time because of their beneficial health effects, although their nutrient composition was not clear at that time. The sour jujube seeds were used to treat insomnia, which could be related to the jujuboside A and B in the seeds and their sedative effect (Fang et al., 2010). Jujuboside A and B are also found in the seeds of Z. jujuba (Otsuka et al., 1978). As a result of its ability to inhibit platelet aggregation, jujuboside $\mathrm{B}$ could also be used in preventive or therapeutic herbal medicine for cardiovascular disease (Seo et al., 2012).

Jujube fruit is high in sugar, vitamins, edible cellulose, minerals, cyclic adenosine monophosphate (cAMP), and cyclic guanosine monophosphate (cGMP) (Church, 1924; Guo and Shan, 2010; Liu, 2006; Liu and Wang, 1991). Jujube fruit has much higher sugar concentration than most temperate fruits like apples, peaches, and grapes. The soluble solids content of grapes can reach $22 \%$ to $25 \%$, but for jujubes, $30 \%$ soluble solids content is not rare and some cultivars can reach 40\% (Meyer, 1991b). Wang et al. (1956) reported the ascorbic acid (vitamin C) content of jujube fruit to be 300 to $500 \mathrm{mg} /$ $100 \mathrm{~g}$ fresh weight and 800 to $1000 \mathrm{mg} / 100 \mathrm{~g}$ fresh weight for Z. spinosa. Bi et al. (1990) tested the vitamin $C$ content of 121 jujube cultivars and found an average of $412 \mathrm{mg} / 100 \mathrm{~g}$ and a range from 166 to $808 \mathrm{mg} / 100 \mathrm{~g}$ with fresh-eating cultivars containing less vitamin $\mathrm{C}$ than drying cultivars. However, most of the vitamin $\mathrm{C}$ gets lost during the sun-drying process, and on average only $10 \%$ remains. So, for the benefit of vitamin $\mathrm{C}$, eating fresh jujube fruit is much better than eating dried fruit. The USDA recommended daily vitamin C

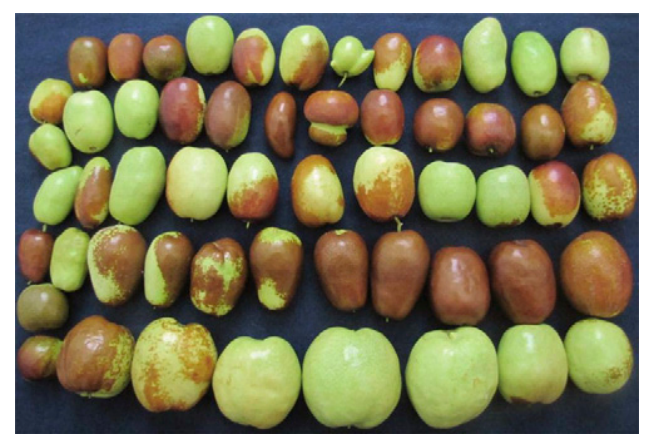

Fig. 3. Jujube cultivars with different sizes and shapes grown at Alcalde, NM, in 2012 (Photo by S. Yao).

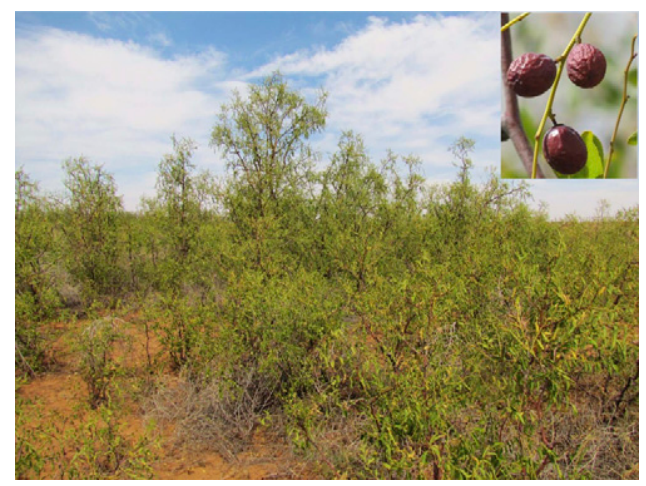

Fig. 4. Eighty-year-old, naturally spreading jujube patch at Tucumcari, NM, 2012. There were several patches there ranging from 0.2 to 0.5 ha each. The few old original plantings could still be seen in the middle and they spread out naturally by seeds or by root suckers. They might have set fruit during years with heavy rainfall, but during most years, they likely set few fruit and struggled to obtain enough water without irrigation. The average annual precipitation at Tucumcari is $409 \mathrm{~mm}$. The species is Z. jujuba with small fruit (Photo by S. Yao). 
requirements are $90 \mathrm{mg}$ for men and $75 \mathrm{mg}$ for women, and based on the average vitamin $\mathrm{C}$ content, 20 to $30 \mathrm{~g}$ of fresh jujube/day (one to three fruit depending on the fruit size) would meet this requirement.

Cyclic adenosine monophosphate was first isolated from jujube fruit in 1980 (Cyong and Hanabusa, 1980) and cGMP in 1982 (Cyong and Takahashi, 1982). It was found that cAMP and cGMP from jujube fruits had the same physicochemical properties as pure cAMP and cGMP. The cAMP content of jujube fruits ranged from 100 to $150 \mathrm{nmol} \cdot \mathrm{g}^{-1}$ of fresh fruit and from 100 to $600 \mathrm{nmol} \cdot \mathrm{g}^{-1}$ of dried jujube fruit, and the cGMP content was 30 to $60 \mathrm{nmol} \cdot \mathrm{g}^{-1}$ dried fruit and it increased 90 times as the fruit ripened (Cyong and Takahashi, 1982; Qu et al., 1987). Liu and Wang (1991) reported the highest cAMP in jujube cultivar Muzao at $303 \mathrm{nmol} \cdot \mathrm{g}^{-1}$ fresh weight (756 nmol. $\mathrm{g}^{-1}$ dry weight), which is the highest known in higher plants. Cyong and Hanabusa (1980) found jujube cAMP content 10 times higher than all other fruit tested. Zhao et al. (2009) studied the cAMP and cGMP contents in different jujube cultivars, development stages, and organs. The cAMP is a second messenger in our body, and the jujube fruit could be used as a natural source of cAMP (Li, 2012). (As for cAMP's medical effects, please refer to Serezani et al., 2008.)

Jujube fruit also have high total phenol contents and total antioxidant activity (Kamiloglu et al., 2009; Li et al., 2005). In the 1920 s, people paid attention to sugar and protein content and compared jujubes with dried palm date and figs (Church, 1924). Currently, with higher health awareness, people pay more attention to the benefits fruit provides, like ascorbic acid, phenols, antioxidants, and medicinal effects. Consumers would accept jujube fruit much easier than in the 1920s. It is expected that the jujube commercial production era could be imminent in the United States.

\section{Jujube Propagation}

Jujube grafting has been recorded in the oldest Chinese farming book, "Qi Min Yao Shu" (Essential farming skills for the common people), which was published 1400 years ago (Guo and Shan, 2010). However, in practice, the most widely used method of jujube propagation was by root suckers in China until the 1960s. After the 1980s, as more new cultivars were selected and released, jujube grafting with sour jujube rootstocks became increasingly popular. In traditional jujube-growing regions, people still used root suckers to propagate because their trees were from root suckers and their new suckers still produced fruit identical to the mother plants. In new production areas, plants were grafted and the suckers only used as rootstocks for grafting, not directly for planting. Researchers also tried softwood cuttings (Sheng et al., 2008) and tissue culture propagation of jujubes (Wang et al., 2009), but grafting is still the most popular propagation method. T-budding, which is popularly used in pome and stone fruit propagation, does not work well for jujubes as a result of their shoot and bud structure and their thin bark. Whip tongue grafting, bark grafting, and cleft grafting are the most popular and successful grafting methods (Guo et al., 1994). Whip grafting requires that the diameters of the scionwood and rootstock are similar. This grafting method is the most difficult to perform, but it can use the small rootstocks, and windbreak is rare after grafting. Bark grafting needs to be done in the growing season when the cambium layer is active, and its operation is easier than whip grafting. Cleft grafting and side grafting can also be used in addition to bark and whip grafting; cleft grafting is used with big rootstocks, and side grafting can be used in warmer areas. With jujube's hard wood and lack of T-budding, jujube grafting is more challenging than other fruit tree species. However, with a combination of whip grafting and bark grafting around tree budding time and several weeks after that, the author achieved 95\% grafting success in northern New Mexico.

The majority of jujube plants sold from nurseries now are grafted plants on sour jujube rootstocks. However, for those scattered old plantings in people's backyards, some are on their own roots and their suckers are identical with the mother plants, which can be used directly for planting. This is especially useful for home gardeners who want to get a jujube plant from friends or neighbors.

\section{Pests and Diseases}

The dominant jujube diseases in China are witches-broom and fruit splitting/cracking. Witches-broom is widespread in jujubeproducing areas in China, Korea, and Japan (Guo and Shan, 2010; Jung et al., 2003; Zhou et al., 1998). It can wipe out a whole orchard, and there is no cure except for preventive management. Witches-broom is caused by a phytoplasm, 'Candidatus Phytoplasma ziziphi' (Jung et al., 2003). The leafhopper species Hishimonus sellatus Uhler (RLH) (Doi et al., 1967), Hishimonoides chinensis (Wang et al., 1984), Hishimonodies aurifavialea, and Typhlocyba sp. (Chen et al., 1984) were reported as vector insects for jujube witchesbroom disease.

Fruit splitting/cracking is a water-related physiological disorder that can ruin the whole crop in some extreme years. The severity of the problem depends on water management during the growing season, precipitation around the fruit maturation season, and cultivar resistance to splitting. Guo and Shan (2010) mentioned that serious splitting and fruit rot happened once every 5 years with $40 \%$ fruit loss in Laoling County, Shandong Province. Maintaining a stable water supply during the growing season will ease splitting, but the cultivar is what makes the ultimate difference.
The most important insect problem on jujubes in China is peach moth (Carposina nipponensis) damage to fruit. There are also other insects that damage leaves. In the United States, the pest and disease pressure for jujubes is low at this time. Most researchers in the United States mentioned that there were no pests and diseases for jujubes thus far (Ashton, 2006; Locke, 1955; Lyrene, 1979). We have yet to see disease problems in New Mexico, but we occasionally noticed peach moth damage to the sour jujube fruit that was collected in Las Cruces, NM, for seeds that will be used for rootstocks. In California, growers have complained about bird damage to fruit (Roger Meyer, personal communication).

\section{Jujube-related Research in the United States}

Formal jujube research started when the big-fruited cultivars were imported to the USDA Plant Introduction Station at Chico, $\mathrm{CA}$, in 1908. Scientists evaluated the imported cultivars, propagated them at Chico, dispersed them to other USDA stations for evaluation (Locke, 1948), recommended cultivars, tested their nutrient value, researched their pollination and fruit set (Ackerman, 1961), and conducted jujube cultivar breeding/ selection. Bonner and Rudolf (1974) tested jujube and sour jujube seed germination and found that jujube and sour jujube seeds could germinate directly, but stratification for 2 to 3 months increased the germination rate; water soaking at 21 to $37.8{ }^{\circ} \mathrm{C}$ for $2 \mathrm{~d}$ also prompted $Z$. spina-christi seed germination. Outlaw et al. (2001) studied the jujube nectar composition and found it was dominated by sucrose with $40 \%$ total sugar content. Jujube flowers attracted 18 species of insects, including bees, flies, and beetles, but honeybee numbers were not high in the netted insects. Kader et al. (1982) studied the postharvest storage of jujubes at the University of California-Davis and found that jujubes were high in sugar and total phenols but low in titratable acid. They also indicated that jujube's high ascorbic acid puts it near the top of the list of fruits for vitamin C sources. The jujube fruits were stored at $0{ }^{\circ} \mathrm{C}$ for $26 \mathrm{~d}$ and exhibited chilling injury of pitting (Kader et al., 1982). Lyrene (1983) observed 18 jujube cultivars flowering and fruiting in Florida and noticed two blooming types with varied fruit set. He concluded the heavily fruited cultivars were parthenocarpic such as 'Silverhill' and 'Leon Burk', which were recommended for the southeast United States. Sweet (1985) discussed jujube cultivars, propagation, and production in his article and predicted a large market potential for Chinese jujubes in the United States. There were quite a few people across the country from the North American Fruit Explorers group who tested jujubes in their own yards or orchards. In general, jujube research is very limited in the United States, and there are almost no research publications after 2001 . 


\section{Jujube Uses/Processing Products}

When jujube fruits are close to maturity, their skin color turns from dark green to light green/creamy with high vitamin $\mathrm{C}$ content (white mature stage). The soluble solid content measures $\approx 20 \%$ for most cultivars. The fruit then change color and become half cream/half red and eventually turn fully red/ brown (crisp mature stage). At this stage, the fruit becomes crispy, sweet, and juicy with high sugar and acid content. The fruit skin gets thicker, harder, and easier to separate from the flesh after boiling. Fruit have the best fresh-eating quality at this point, but the vitamin $\mathrm{C}$ content starts to decrease. After that, the skin of the fruit will wrinkle and start to dehydrate and the flesh color near the kernel changes from greenish white to yellow/light brown and turns soft. Sugar and acid contents continue to increase, and vitamin $\mathrm{C}$ content continues to decrease (fully mature stage). Depending on the purpose, jujube fruit can be picked from the white mature stage, to the crisp mature stage, or the fully mature stage. Fresh-eating cultivars can be picked from the white mature stage until the crisp mature stage when the fruit texture is still firm.

Red date (dry date). Red date is the dominant jujube product for the domestic and export markets in China. Fruits are picked when they are fully red or the fully mature stage because the more mature they are, the higher their sugar content and drying quality. After picking, fruits can be air-, sun-, or heat-dried. Heat drying is the optimal method because it retains more vitamin $C$, leads to better fruit quality, and avoids disease-related fruit losses. Red date can be consumed directly as snacks; used in porridge, stew, soup, or tea; or processed further as jujube paste or other products. "Zongzi" is a traditional Chinese food that is consumed near the Dragon Boat Festival to remember the patriotic poet, Qu Yuan. Red dates are placed in the middle of sweet rice, which is then wrapped by bamboo or reed leaves and cooked for 2 to $3 \mathrm{~h}$. After the cooking process, the red date is sweet, tasty, and gives the surrounding glutinous sweet rice great flavor. The red dates of small-sized cultivars like 'Jin sze tsao' and 'Wu hu tsao' (pitless) are excellent when cooked with rice or millet in porridge (Meyer, 1911).

Candied jujube (honey jujube). Frank Meyer (1911) mentioned the cooking process of honey jujubes, which have been popular in China for $\approx 200$ years. Fruits are picked at white mature stage and $60 \%$ to $80 \%$ of vitamin $\mathrm{C}$ content can be kept, which is much higher than the sun-dried jujube. Fruit surfaces are sliced with rows of blades or needles to enhance sugar-soaking and product appearance (Guo and Shan, 2010).

Spirited jujube ('drunk' jujube). Fruits are picked during the fully red stage and $60 \%$ to $70 \%$ of the vitamin $\mathrm{C}$ content is preserved. Spirits of 130 to 140 proof or good-quality hard liquor is used for this product. The jujube fruits are poured into the liquor and fully covered with liquor. They are then sealed in jars or zip bags and can be stored for 6 months to 1 year. They can also be sealed in small packages and sold directly in those packages several months later (Guo and Shan, 2010).

Smoked jujube. This product is mainly produced from the cultivar Yuan ling tsao in Shandong Province. Fruits are picked at the fully red stage, precooked in boiling water, and then smoked. The product can be eaten directly or used in cooking.

Roasted jujube. Red dates are used for this purpose. The fruit are first pitted and then sliced vertically to pieces $\approx 3 \mathrm{~mm}$ wide before roasting. Fully mature fresh fruit of drying cultivars can also be used but require a longer roasting time than using dried fruit.

Jujube jam. Full red fruits are also used for jam, which can preserve $65 \%$ to $80 \%$ of the vitamin $\mathrm{C}$ content. The fruit needs to be skinned and pitted for this purpose.

Jujube paste/filling. Jujube filling is widely used in the pastry industry in China; it is one of the traditional fillings of mooncakes (Guo and Shan, 2010; Yao, 2012a). It can also be directly spread over bread.

Jujubes can also be used to make juice, wine, and vinegar, whereas the red date is also widely used in the culinary world.

The Chinese and Southeast Asian populations in the United States are used to having jujubes in their diets, consuming them fresh, dried, or processed. If we promote jujubes and want the rest of Americans to consume them, American-style jujube products are needed. There are a few recipes listed at Ashton (2006), California Rare Fruit Growers (1996), and Guggenheim (1994).

Eating fresh would be the easiest way for Americans to accept the fruit. The author conducted some jujube fruit-tasting workshops, including the New Mexico State Fair, and with school kids through the Cooking with Kids program in Santa Fe, NM. Most people who tasted the fruit liked them. Fresh jujubes have an apple-like texture without any strong flavor and are sweet and nutritious. With a good promotion program, it would not be difficult for the public to accept this nutritious fruit. Fresh fruit can also be used solely in pie or together with apples. It seems the ascorbic acid preserved well for products cooked with fresh fruit (S. Yao, unpublished data), which would be beneficial because people have more concern about health than before. Fresh fruit can also be used in ice cream or fruit salad or processed into jam.

Dried jujubes can be directly used in fruit and nut mixes or used to replace raisins or palm dates in baking for cakes, tarts, or other pastry products or baked goods. Jujube paste can be used directly as a spread or used as filling for other pastries. A popular product is needed to promote the jujube and to develop a viable market.

Jujube is also a multipurpose plant (Outlaw et al., 2002). Except for its fruit, jujube is a nice nectar plant with a long blooming period and jujube honey is popular in
China. Its seeds, especially the seeds from Z. spinosa, are a famous traditional Chinese herb, "Suanzaoren" (Qu et al., 1987). Its wood is very hard and good for instruments or utensils.

\section{Challenges and Opportunities: Why Not an Industry Yet?}

When jujubes entered the United States, Frank Meyer and other researchers who worked with jujube were impressed with jujube's fruit quality and nutrient content, wide adaptability, reliability, lack of frost damage, drought tolerance, and easy care (Lanham, 1926; Meyer, 1911). They predicted a bright future in the United States, especially in the Southwest (Lanham, 1926). There was another round of interest in jujubes beginning in the 1980s, especially among the members of the California Rare Fruit Growers and the North American Fruit Explorers. Growers and home gardeners had big interests in jujubes and wanted to promote jujubes in the United States. Roger Meyer wrote a series of papers about jujube culture, propagation, fruit use, and cultivar collection (Meyer, 1988, 1989, 1991a, 1991b, 1994; Meyer and Meyer, 1994a, 1994b). Jujube was the "Fruit of the Year" for the California Rare Fruit Growers in 1994 (Guggenheim, 1994). However, lack of research support, propagation hurdles, limited cultivars, and lack of marketing, promotion, and Americanstyle products all restrict jujube's adoption in the United States.

After hosting a "jujube-growing habits and pruning workshop" in the spring and "jujube flowering, fruiting, and fruit-tasting workshop" in the fall for 3 years, more and more people are interested in jujubes in New Mexico and the nearby states. Currently, nurseries have a hard time meeting the jujube plant demands. Realizing the challenges for commercial jujube production, these areas are what scientists should focus on; pomologists should conduct research on pollen germination, fruit set, cultivar regional trials, and culture practices with the goal of recommending more cultivars to the growers. Extension specialists should write more jujube publications, educate the public, and guide the commercial jujube production. Food scientists should experiment with Americanstyle jujube products while agricultural marketing specialists work on jujube promotion and marketing. Growers can start small and expand gradually. With big cities like San Francisco and New York, it would be an easy start through targeting the Asian population and Asian markets with fresh fruit or dried fruit (red date). As more and more people come to know this exotic fruit, free sampling at local markets would enhance customers' acceptance. The basic foundation is solid: with jujube's wide adaptation to soil and weather conditions, it does grow and produce well in the southern and southwestern United States with excellent fruit quality. Jujube is an excellent backyard tree for home gardeners, serving dual purposes for its fruit 
and tree. With continuous research and extension input plus good promotion strategies, after 15 to 20 years, jujube production could become a valuable industry in the United States.

\section{Literature Cited}

Ackerman, W.L. 1961. Flowering, pollination, self-sterility and seed development of Chinese jujube. Proc. Amer. Soc. Hort. Sci. 77:265269.

Ashton, R. 2006. Jujube-The chinese date. Third Millennium Publishing. Tempe, AZ.

Ashton, R. 2008. Jujube-A fruit well adapted to Texas. Texas Gardeners. 20 Feb. 2013. <http:// www.texasgardener.com/pastissues/janfeb08/ Jujube.html>.

Atkins, J.S. 1987. "He did it again." Pomona 20: $40-41$.

Baloda, S., S.K. Sehrawat, B.S. Yadav, V.P. Ahlawat, and S. Singh. 2012. Present statis of ber production and future thrists in India-A review. Agr. Rev. 33:256-264.

Bi, P., Z. Kang, F. Lai, and X. Lu. 1990. Fruit vitamin $C$ content changes of different jujube cultivars. Shanxi Fruit 4:24-25 [in Chinese].

Bonner, F.T. and P.O. Rudolf. 1974. Ziziphus Milljujube, p. 862-863. In: Schopmeyer, C.S. (ed.). Seeds of wood plants in the United States. Agricultural handbook no. 450. USDA Forest Service, Washington, DC.

Brubaker, M.M. 1977. The jujube in the Philadelphia area. The North American Pomona. 10: 82-83.

California Rare Fruit Growers. 1996. Jujube, Ziziphus jujuba Mill. 12 Feb. 2013. <http://www. crfg.org/pubs/ff/jujube.html>.

Chen, Z., F. Zhang, X. Tian, and J. Zhang. 1984. Transmission of jujube witches' broom disease. Acta Phytopathologica Sin. 14:142-146 [in Chinese].

Church, C.G. 1924. Composition of the chinese jujube, p. 24-29. In: Thomas, C.C. (ed.). The chinese jujube. USDA Bul. no. 1215. Washington, DC.

Cyong, J. and K. Hanabusa. 1980. Cyclic adenosine monophosphate in fruits of Zizyphus jujuba. Phytochemistry 19:2747-2748.

Cyong, J. and M. Takahashi. 1982. Identification of guanosine $3^{\prime}: 5^{\prime}$-monophhosphate in the fruit of Zizyphus jujuba. Phytochemistry 21: 1871-1874.

Doi, Y., K. Teranaka, and H. Asuyama. 1967. Mycoplasma- or PLT-group-like microorganisms found in the phloem elements of plants infected with mulberry dwarf, potato witchesbroom, aster yellows, or paulownia witchesbroom. Ann. Phytopathological Soc. Jpn. 33: 259-266.

Fairchild, D. 1918. The grafted jujube of China. Heredity 9:2-7.

Fairchild, D. 1920. Foreign plant introduction medal-Memorial to the late Frank N. Meyer presented to Mr. Barbour Lathrop "for distinguished service in the field of Foreign Plant Introduction.” J. Hered. 11:168-173.

Fang, X., J. Hao, F. Song, J. Wang, H. Zhou, and L. Zhu. 2010. Pharmacological studies on the sedative-hypnotic effect of Semen Ziziphi spinosae (Suanzaoren) and Redix et Rhizoma Salviae miltiorrhizae (Danshen) extracts and the synergistic effect of their combinations. Pytomedicine 17:75-80.

Galloway, T.A., USDA. 1907. Seeds and plants imported during the period of Dec. 1905 to July 1906. Inventory no. 12. Nos. 16797 to 19057. USDA Bur. Plant Ind. Bul. No. 106. 28 Dec.
2012. <http://www.ars-grin.gov/npgs/pi_books/ scans/pi012.pdf $>$.

Galloway, T.A., USDA. 1908. Seeds and plants imported during the period of Dec. 1905 to July 1906. Inventory no. 13. Nos. 19058 to 21730. USDA Bur. Plant Ind. Bul. No. 132. 28 Dec. 2012. <http://www.ars-grin.gov/npgs/pi_books/ scans/pi013.pdf $>$.

Galloway, T.A., USDA. 1909a. Seeds and plants imported during the period Seeds and plants imported during the period of $1 \mathrm{Jan}$. to 31 Mar. 1908, inventory No. 14; Nos. 21732 to 22510. USDA Bur. Plant Ind. Bul. No. 137. 28 Dec. 2012. <http://www.ars-grin.gov/npgs/pi_books/ scans/pi014.pdf $>$.

Galloway, T.A., USDA. 1909b. Seeds and plants imported during the period of 1 April to 30 June 1908. Inventory no. 15. Nos. 22511 to 23322. USDA Bur. Plant Ind. Bul. No. 142. 28 Dec. 2012. <http://www.ars-grin.gov/npgs/pi_books/ scans/pi015.pdf $>$.

Galloway, T.A., USDA. 1909c. Seeds and plants imported during the period of 1 July to 30 Sept. 1908. Inventory no. 16. Nos. 23323 to 23744. USDA Bur. Plant Ind. Bul. No. 148. 28 Dec. 2012. <http://www.ars-grin.gov/npgs/pi_books/ scans/pi016.pdf>.

Galloway, T.A., USDA. 1910. Seeds and plants imported during the period of 1 July to 30 Sept. 1909. Inventory no. 20. Nos. 25718 to 26047. USDA Bur. Plant Ind. Bul. No. 176. 28 Dec. 2012. <http://www.ars-grin.gov/npgs/pi_books/ scans/pi020.pdfs.

Galloway, T.A., USDA. 1911a. Seeds and plants imported during the period of 1 Oct. to $31 \mathrm{Dec}$. 1909. Inventory no. 21. Nos. 26048 to 26470. USDA Bur. Plant Ind. Bul. No. 205. 28 Dec. 2012. <http://www.ars-grin.gov/npgs/pi_books/ scans/pi021.pdf $>$.

Galloway, T.A., USDA. 1911b. Seeds and plants imported during the period of 1 July to 30 Sept. 1910. Inventory no. 24. Nos. 28325 to 28880. USDA Bur. Plant Ind. Bul. No. 223. 28 Dec. 2012. <http://www.ars-grin.gov/npgs/pi_books/ scans/pi024.pdf>.

Galloway, T.A., USDA. 1911c. Seeds and plants imported during the period of 1 Oct. to 31 Dec. 1910. Inventory no. 25. Nos. 28883 to 29327. USDA Bur. Plant Ind. Bul. No. 227. 28 Dec. 2012. <http://www.ars-grin.gov/npgs/pi_books/ scans/pi025.pdf>.

Galloway, T.A., USDA. 1911d. Seeds and plants imported during the period of 1 Jan. to 31 Mar. 1911. Inventory no. 26. Nos. 29328 to 30461. USDA Bur. Plant Ind. Bul. No. 233. 28 Dec. 2012. <http://www.ars-grin.gov/npgs/pi_books/ scans/pi026.pdf>.

Galloway, T.A., USDA. 1912. Seeds and plants imported during the period of 1 July to 30 Sept. 1911. Inventory no. 28, Nos: 31371 to 31938 . USDA Bur. Plant Ind. Bul. No. 248. 28 Dec. 2012. <http://www.ars-grin.gov/npgs/pi_books/ scans/pi028.pdf>.

Guggenheim, C.A. 1994. Jujube is the star this year. Fruit Gardener. 26:21.

Guo, Y. and G. Shan. 2010. The chinese jujube. Shanghai Scientific and Technical Publishers, Shanghai, China [in Chinese].

Guo, Y., B. Wang, and S. Yao. 1994. Jujube nursery grafting and management. Deciduous Fruits 1:30-32 [in Chinese].

Hager, M.D. and T. Edward. 1989. My favorite tree, the jujube. California Rare Fruit Growers Newsletter 21:31-32.

Jung, H.-Y., T. Sawayanagi, S. Kakizawa, H. Nishigawa, W. Wei, K. Oshima, S. Miyata, M. Ugaki, T. Hibi, and S. Manba. 2003. 'Canadidatus phytoplasms ziziphi', a novel phytoplasm taxon associated with jujube witches'-broom disease. Intl. J. Syst. Evol. Microbiol. 53:1037-1041.

Kader, A.A., Y. Li, and A. Chordas. 1982. Postharvest respiration, ethylene production, and compositional changes in chinese jujube fruits. HortScience 17:678-679.

Kamiloglu, O., S. Ericisli, M. Sengul, C. Toplu, and S. Serce. 2009. Total phenolics and antioxidant activity of jujube (Zizyphus jujuba Mill.) genotypes selected from Turkey. Afr. J. Biotechnol. 8:303-307.

Lanham, W.B. 1926. Jujubes in Texas. Texas Agr. Exp. Sta. Circular 41

Li, J., S. Ding, and X. Ding. 2005. Comparison of antioxidant capacities of extracts from five cultivars of chinese jujube. Process Biochem. 40:3607-3613.

Li, Y. 2012. Research advances of cAMP in Ziziphus jujuba. Food Res. Dev. 33:230-231 [in Chinese].

Liu, M. 2006. Chinese jujube: Botany and horticulture. Hort. Rev. 32:229-298.

Liu, M. 2008. China jujube development report. China Forestry Publishing House, Beijing, China [in Chinese].

Liu, M. and Y. Wang. 1991. CAMP content of Ziziphus jujuba Mill., Ziziphus spinosus $\mathrm{Hu}$ and other twelve horticultural plants. J. Hebei Agr. Univ. 14:20-23 [in Chinese].

Locke, L.F. 1948. The chinese jujube: A promising fruit tree for the southwest, p. 78-81. In: Oklahoma Crops and Soils, 1947: Research reported at the Second Annual Oklahoma Crops and Soils Conference. Oklahoma Agr. Expt. Sta. Bul. B319.

Locke, L.F. 1955. Growing fruits and nuts in the Southern Great Plains. USDA Farmers Bul. No. 2087.

Lyrene, P.M. 1979. The jujube tree. Fruit Var. J. 33:100-104.

Lyrene, P.M. 1983. Flowering and fruiting of chinese jujubes in Florida. HortScience 18: 208-209.

Lyrene, P.M. and R.E. Crocker. 1994. The Chinese jujube. Univ. Florida Coop. Ext. Serv. Fact Sheet HS-50.

Meyer, F.N. 1911. Agricultural explorations in the fruit and nut orchards of China. USDA Bur. Plant Ind. Bul. No. 204. 28 Dec. 2012. <http://books. google.com/books?id=GqQUAAAAYAAJ\& printsec $=$ frontcover $\&$ source $=$ gbs_ge_summary_ $\mathrm{r} \& \mathrm{cad}=0 \# \mathrm{v}=$ onepage \&q\&f$=$ false $>$.

Meyer, F.N. 1916. China a fruitful field for plant exploration, p. 205-224. In: USDA yearbook of agriculture 1915. U.S. Dept. Agr., Washington, DC. 28 Dec. 2012. <http://naldc.nal.usda.gov/ download/IND43843025/PDF>.

Meyer, R. 1988. Renaissance of the jujube test group. Pomona 21:51-52.

Meyer, R. 1989. Jujube grafting. Pomona 22: 59-61.

Meyer, R. 1991a. The jujube and the plant introduction station at Chico, California. Pomona 24:31-35.

Meyer, R. 1991b. Sugar levels of ripe jujube fruit Pomona 24:78-79.

Meyer, R. 1994. Varieties of jujube, aka chines date. Fruit Gardener 26:14-16.

Meyer, R. and S. Meyer. 1994a. Can an unknown become a winner? Fruit Gardener 26:4-5.

Meyer, R. and S. Meyer. 1994b. Planting and care of jujubes: The first year. Fruit Gardener 26:8-9.

Osborn, D.A. and K.V. Miller. 2009. Meet the jujube. Quality Whitetails 2009:60-66.

Otsuka, H., R. Akiyarna, K.I. Hawai, S. Shibata, O. Onoue, and Y. Ogihara. 1978. The structure 
of jujubosides A and B, the saponins isolated from the seeds of Ziziphus jujuba. Phytochemistry 17:1349-1352.

Outlaw, W.H., Jr., S. Zhang, K.A. Riddle, A.K. Womble, L.C. Anderson, W.M. Outlaw, N.N. Outlaw, E.C. Outlaw, and A.B. Thistle. 2002. The jujube (Ziziphus jujuba Mill.), a multipurpose plant. Econ. Bot. 56:199-200.

Outlaw, W.H., Jr., S. Zhang, W.R. Tschinkel, R.G. Smith, E.C. Outlaw, and N.N. Outlaw. 2001. Chemical and biological attributes of the nectar of the jujube (Ziziphus jujuba Mill.). Am. Bee J. 141:61-62.

Plantexplorers.com. 2012. Frank Nicolas Meyer (1875-1918). 28 Nov. 2012. <http://www. plantexplorers.com/explorers/biographies/meyer/ frank-nicholas-meyer.htm>.

Qu, Z. 1963. Ancient cultivation of chinese jujube in China. J. Hebei Agr. Univ. 2:1-18 [in Chinese].

Qu, Z., Y. Wang, and M. Liu. 1987. A review of chemical constituents of Ziziphis spinosus (Bunge) $\mathrm{Hu}$. and pharmacodynamics of its seeds. J. Hebei Agr. Univ. 10:60-66 [in Chinese].

Rehder, A. and G.P. Rixford. 1929. Zizyphus, p. 3547-3548. In: Bailey, L.H. (ed.). The standard cyclopedia of horticulture. MacMillan, New York, NY.

Seo, E.J., S.Y. Lee, S.S. Kang, and Y. Jung. 2012. Ziziphus jujuba and its active components jujuboside B inhibit platelet aggregation. Phytotherapy Res. First published online 15 Aug. 2012. 20 Feb. 2013. <http://onlinelibrary.wiley. com/doi/10.1002/ptr.4809/abstract $>$.

Serezani, C.H., M.N. Ballinger, D.M. Aronoff, and G. Peters-Golden. 2008. Cyclic AMPMaster regulator in innate immune cell function. Amer. J. Respir. Cell Mol. Biol. 39:127-132.

Sheng, C., S. Cao, S. Xie, J. Guo, Y. Cheng, and H. Xue. 2008. The effects of rooting powder and transferring media on jujube young shoot cuttings. China Fruits 2:38-40 [in Chinese].

Sweet, C. 1985. Large market potential seen for the chines date (jujube). California Grower: Avocados, Citrus, Subtropicals 12:41-43, 48.

Taylor, W.A., USDA. 1914a. Inventory of seeds and plants imported by the Office of Foreign Seed and Plant Introduction during the period from 1 Apr. to 30 June 1912. Inventory. no. 31. Nos. 33279 to 34092 . USDA Bur. Plant Ind. Washington, DC. 28 Dec. 2012. <http://www. ars-grin.gov/npgs/pi_books/scans/pi031.pdf $>$.

Taylor, W.A., USDA. 1914b. Inventory of seeds and plants imported by the Office of Foreign Seed and Plant Introduction during the period from 1 July to 30 Sept. 1912. Inventory. no. 32.
Nos. 34093 to 34339. USDA Bur. Plant Ind. Washington, DC. 28 Dec. 2012. <http://www. ars-grin.gov/npgs/pi_books/scans/pi032.pdf $>$.

Taylor, W.A., USDA. 1915. Inventory of seeds and plants imported by the Office of Foreign Seed and Plant Introduction during the period from 1 Jan. to 31 Mar. 1913. Inventory. no. 34. Nos. 34728 to 35135 . USDA Bur. Plant Ind. Washington, DC. 28 Dec. 2012. <http://www. ars-grin.gov/npgs/pi_books/scans/pi034.pdf $>$.

Taylor, W.A., USDA. 1916a. Inventory of seeds and plants imported by the Office of Foreign Seed and Plant Introduction during the period from 1 Apr. to 30 June 1913. Inventory. no. 35. Nos. 35136 to 3566 . USDA Bur. Plant Ind. Washington, DC. 28 Dec. 2012. <http://www. ars-grin.gov/npgs/pi_books/scans/pi035.pdf>.

Taylor, W.A., USDA. 1916b. Inventory of seeds and plants imported by the Office of Foreign Seed and Plant Introduction during the period from 1 Oct. to 31 Dec. 1913. Inventory no. 37. Nos: 36259 to 36936 . USDA Bur. Plant Ind. Washington, DC. 28 Dec. 2012. <http://www. ars-grin.gov/npgs/pi_books/scans/pi037.pdf $>$.

Taylor, W.A., USDA. 1917a. Inventory of seeds and plants imported by the Office of Foreign Seed and Plant Introduction during the period from 1 Jan. to 31 Mar. 1914. Inventory no. 38. Nos: 36937 to 37646 . USDA Bur. Plant Ind. Washington, DC. 28 Dec. 2012. <http://www. ars-grin.gov/npgs/pi_books/scans/pi038.pdf $>$.

Taylor, W.A., USDA. $1917 \mathrm{~b}$. Inventory of seeds and plants imported by the Office of Foreign Seed and Plant Introduction during the period from 1 Apr. to 30 June 1914. Inventory no. 39. Nos: 37647 to 38665 . USDA Bur. Plant Ind. Washington, DC. 28 Dec. 2012. <http://www. ars-grin.gov/npgs/pi_books/scans/pi039.pdf $>$.

Taylor, W.A., USDA. 1917c. Inventory of seeds and plants imported by the Office of Foreign Seed and Plant Introduction during the period from 1 Oct. to 31 Dec. 1914. Inventory. no. 41. Nos. 39309 to 39681. USDA Bur. Plant Ind. Washington, DC. 28 Dec. 2012. <http://www. ars-grin.gov/npgs/pi_books/scans/pi041.pdf>.

Taylor, W.A., USDA. 1919. Inventory of seeds and plants imported by the Office of Foreign Seed and Plant Introduction during the period from 1 Jan. to 31 Mar. 1916. Inventory. no. 46. Nos. 41685 to 42383 . USDA Bur. Plant Ind. Washington, DC. 28 Dec. 2012. < http://www. ars-grin.gov/npgs/pi_books/scans/46.pdf $>$.

Taylor, W.A., USDA. 1922a. Inventory of seeds and plants imported by the Office of Foreign Seed and Plant Introduction during the period from 1 Jan. to 31 Mar. 1917. Inventory no. 50 Nos. 43980 to 44445 . USDA Bur. Plant Ind.
Washington, DC. 28 Dec. 2012.<http://www. ars-grin.gov/npgs/pi_books/scans/pi050.pdf $>$.

Taylor, W.A., USDA. 1922b. Inventory of seeds and plants imported by the Office of Foreign Seed and Plant Introduction during the period from 1 Apr. to 30 June 1917. Inventory no. 51. Nos. 44446 to 44934 . USDA Bur. Plant Ind. Washington, DC. 28 Dec. 2012. <http://www. ars-grin.gov/npgs/pi_books/scans/pi051.pdf>.

Thomas, C.C. 1927. Chinese jujube in southwestern United States. p.212-215. In USDA yearbook of agriculture 1926. U.S. Dept. Agr., Washington, DC. 28 Dec. 2012. < http://naldc. nal.usda.gov/download/IND43842740/PDF>.

Thomson, P.H. 1971. Deciduous fruits for southern California. CRFG Newsletter 3:7.

Wang, H., Z. Chen, Z. Li, R. Wang, and Q. Zhou. 1956. The ascorbic acid content of jujube and its utilization by human subjects. Ying Yang Xue Bao 1:15-24 [in Chinese].

Wang, J., L. Liu, M. Liu, and J. Zhou. 2006. Acquirement of new male sterile germplasm of chinese jujube. Acta Hort. Sinica 33:374377 [in Chinese].

Wang, N., Z. Qin, M. Liu, and D. Xiang. 2009. Study on rapid propagation system for micrografting of three cultivars of Ziziphus jujuba Mill. J. Hebei Normal University of Science and Technology 23:4-6, 33 [in Chinese].

Wang, Z., P. Zhou, B. Yu, X. Jiang, and C. Zhang. 1984. On the bionomics and control of Hishimonoides chinensis Anufriev, the vector of jujube witches' broom disease. J. Plant Protection 4:247-252 [in Chinese].

Xotcfruit (R. Meyer). 2013. Jujube scionwood. 12 Feb. 2013. <http://www.jujubesales.com/ Jujube-Scionwood.php $>$.

Yan, C., P. Liu, M. Liu, J. Wang, D. Kong, and D. Li. 2010. The influencing factors of the fruiting characteristics of Ziziphus jujuba. Scientia Silvae Sinicae 46:78-86 [in Chinese].

Yao, S. 2012a. Jujube, chinese date in New Mexico. New Mexico State Univ. Coop. Ext. Publ. H-330.

Yao, S. 2012b. Jujube flowering and pollen germination. HortScience 47(suppl):S130 (abstr.).

Yao, S. 2013. Unique fruit development of ornamental 'Teapot' jujube. HortTechnology 23:364-368.

Zhao, A., D. Li, Y. Wang, C. Sui, Y. Cao, and Q. Liang. 2009. Study on the contents of cAMP and cGMP in different cultivars, growing periods and organs in chinese jujube. Acta Hort. Sinica 36:1134-1139 [in Chinese].

Zhou, J., M. Liu, and B. Hou. 1998. Advances in research on witches-broom disease of chinese jujube. J. Fruit Science 15:354-359 [in Chinese]. 